\title{
Valós idejü polimeráz láncreakció alkalmazása cytomegalovirus-fertőzés és -reaktiváció nyomon követésére malignus hematológiai betegségek kemoterápiás kezelése során és autológ őssejt-transzplantációt követően
}

\author{
Piukovics Klára dr. ${ }^{1}$ - Terhes Gabriella dr. ${ }^{2}$ - Bereczki Ágnes dr. ${ }^{1}$ \\ Borbényi Zita dr. ${ }^{1}$ - Gurbity Pálfi Tímea dr. ${ }^{1}$ - Kövári Bence dr. ${ }^{3}$ \\ Urbán Edit dr. ${ }^{2}$
}

Szegedi Tudományegyetem, Általános Orvostudományi Kar, ${ }^{1}$ II. Belgyógyászati Klinika és Kardiológiai Központ, ${ }^{2}$ Klinikai Mikrobiológiai Diagnosztikai Intézet, ${ }^{3}$ Pathologiai Intézet, Szeged

\begin{abstract}
Bevezetés: A hematológiai betegek kemo-immun terápiás kezelése és az őssejt-transzplantáció során fellépő fertőzéses komplikációk egyikét képezi a cytomegalovirus-infekció és -reaktiváció. Célkitüzés: A szerzők célja a cytomegalovirusfertőzés és -reaktiváció követése kvantitatív valós idejü polimeráz láncreakció módszerével. Módszer: A szerzők intézetében 2012-2014 között kezelt 96 beteg dokumentációját elemezték retrospektív vizsgálatban. A betegeket az alapbetegség szerint csoportosították (lymphoproliferativ betegségek, akut leukaemiák), valamint megkülönböztették aszerint, hogy történt-e autológ őssejt-transzplantáció vagy sem. Eredmények: Lymphoproliferativ betegség miatt kezeltek 83 beteget, közülük 63 (76\%) részesült autológ őssejt-transzplantációban. A 604 plazmamintából 46 mintában $(7,6 \%)$ igazolódott valós idejű polimeráz láncreakcióval cytomegalovirus-pozitivitás összesen 25 betegből (6 nem transzplantált [18\%], 19 transzplantált [30,2\%]). A valós idejú polimeráz láncreakcióval cytomegalovirus-pozitivitás kétszeres gyakorisággal fordult elő a transzplantált betegcsoportban, azonban $68 \%$-ukban a reaktiváció tünetmentes volt és spontán oldódott. Következtetések: Rutinszerú cytomegalovirus-monitorozás nem szükséges a fenti betegcsoportban, azonban jól meghatározott betegcsoportban klinikai gyanú esetén elvégzett molekuláris teszt lehetővé teszi a korai preemptív kezelést, ezáltal csökkentve a mortalitást. Orv. Hetil., 2016, 157(35), 1403-1409.
\end{abstract}

Kulcsszavak: cytomegalovirus, molekuláris, immunszupprimált

Monitoring cytomegalovirus infection and reactivation using quantitative real-time polymerase chain reaction in patients with haematological malignancies during chemotherapy and after autologous stem cell transplantation

Introduction: Because of the use of chemo-immunotherapeutic drugs, cytomegalovirus infection is one of the most
important infectious complications among patients with haematological malignancies. Aim: The aim of the authors
was to detect cytomegalovirus infection and reactivation using quantitative real-time polymerase chain reaction.
Method: Between 2012 and 2014 , the authors retrospectively analysed 96 patient's medical history hospitalised in
haematology Unit. Patients were grouped on the basis of their underlying diseases (lymphoprolipherative malignan-
cies, acute leukaemias), and the following groups were created: autologous stem cell transplanted and non-trans-
planted groups. Results: Eighty-three patients were treated with lymphoprolipherative disorders, and $63(76 \%)$ of
them underwent autologous stem cell transplantation. Out of the 604 plasma specimens $46(7.6 \%)$ were positive for
the cytomegalovirus desoxyribonucleic acid collected from 25 patients [ 6 non-transplanted (18\%) and 19 from the
transplanted group $(30.2 \%)$ ]. The frequency of cytomegalovirus positivity was doubled in the transplanted patient 
group, however, reactivation was asymptomatic in $68 \%$ of the cases. Conclusions: The routine use of cytomegalovirus monitoring is not necessary in this patient group. In case of suspected cytomegalovirus infection, molecular tests allow early preemptive antiviral therapy, which may decrease the mortality attributed to cytomegalovirus infection.

Keywords: cytomegalovirus (CMV), molecular, immunocompromised

Piukovics, K., Terhes, G., Bereczki, Á., Borbényi, Z., Gurbity Pálfi, T., Kövári, B., Urbán, E. [Monitoring cytomegalovirus infection and reactivation using quantitative real-time polymerase chain reaction in patients with haematological malignancies during chemotherapy and after autologous stem cell transplantation]. Orv. Hetil., 2016, 157(35), 1403-1409.

(Beérkezett: 2016. május 9.; elfogadva: 2016. június 16.)

\section{Rövidítések}

BEAM = carmustine, etoposide, cytosine-arabinoside, melphalan; $\mathrm{CMV}=$ cytomegalovirus; ECIL = European Conference on Infections in Leukaemia; HHV6 = humán herpeszvírus-6; $\mathrm{HL}=$ Hodgkin-lymphoma; HSV $=$ herpes simplex vírus; NHL = non-Hodgkin-lymphoma; $\mathrm{PCR}=$ polimeráz láncreakció; $\mathrm{VZV}=$ varicella-zooster vírus

Hematológiai betegek kemo-immun terápiás kezelése során fellépő komplikációk egyikét képezik a virális eredetű fertőzések, amely ebben az immunkárosodott betegpopulációban jelentős morbiditással és mortalitással jár [1-3]. A fertőzés kialakulhat mint primer infekció vagy a latens fertőzés reaktiválódásával. Reaktivációt gyakran figyelhetünk meg a herpeszvírusok esetén, mint a humán cytomegalovirus (CMV), herpes simplex (HSV), varicella-zooster (VZV) és humán herpeszvírus-6 (HHV-6) -fertőzést követően [1-3]. Lymphoproliferativ betegségek kezelése során a következményes kvantitatív és kvalitatív T-sejt-abnormalitással járó protokollok alkalmazása a fertőzéses komplikációk spektrumában változást eredményezett, amely a CMV-reaktiváció és -betegség gyakoriságának növekedéséhez vezetett [4-10]. CMV-fertőzéssel összefüggő betegség csaknem minden szervet érinthet (1. $A-F)$ ábrák), gyakoribb azonban a tüdő (I. A) és $B$ ) ábra) és a gastrointestinum érintettsége (1.C) és D) ábra) [1-3]. Incidenciája azonban kevésbé jól meghatározott malignus hematológiai betegségekben [11-13]. A különböző nemzetközi tanulmányok súlyos CMV-betegség előfordulását sejt mediálta immundeficiens állapotokban, őssejt- és szolidszerv-transzplantált recipiensekben nagyobb arányban figyelték meg. Más közleményekben CMV-reaktiváció és -fertózés mint szokatlan fertőzéses komplikáció megjelenéséről számoltak be konvencionális kemoterápiás kezelés kapcsán olyan betegekben, akik nem részesültek csontvelő-transzplantációban $[6,8]$. Őssejttranszplantált betegekben a CMV-reaktiváció 30-70\% között változik $[14,15]$. Ez az arány sokkal alacsonyabb nagy dózisú kemoterápiás kezelésben részesülő betegekben vagy autológ őssejt-transzplantáció (ASCT) kapcsán, mint allogén transzplantáció recipienseiben [16]. Az ECIL (Eu- ropean Conference on Infections in Leukaemia) CMV-monitorozási és -kezelési ajánlása alapján [16] nem szükséges a rutinmonitorozás olyan hematológiai betegek kemoterápiás kezelése során, akiknél nem végeznek össejt-transzplantációt vagy ASCT esetén, mivel alacsony a CMV által okozott betegség kialakulásának az esélye, kivéve, ha megelőzően fludarabin-, cladribin-, alemtuzumabkezelésben részesült a beteg, vagy CD34szelektált őssejtgraft került visszaadásra. CMV-szeroprevalencia felnőttekben 55-90\% között változik a fejlődő országokban. A szerológiai vizsgálat hasznos módszer a CMV-infekció rizikóbecslésére, azonban nem alkalmas a CMV-betegség diagnózisára. Ennek igazolására különböző laboratóriumi metodikák ismeretesek, mint a vírustenyésztés, antigenaemia-assay és polimeráz láncreakció (PCR), amelyek közül a kvantitatív valós idejü PCR-vizsgálat (RT-PCR) magas szenzitivitású és egyben a leggyorsabb metodika $[2,17]$. Immunkompromittált állapotokban (kemo-immun terápiás kezelésben részesülők, őssejt- és szolidszerv-transzplantáltak) a CMV-betegség vagy -vírus-reaktiváció detektálására és korai preemptív kezelés megkezdéséhez nélkülözhetetlen az RT-PCR metodika alkalmazása [17].

\section{Módszer}

\section{Adatgyüjtés, betegek és jellemzöik}

A Szegedi Tudományegyetem, II. Belgyógyászati Klinika és Kardiológiai Központ Hematológia és Transzplantációs Részlegén 2012. november és 2014. november közötti időszakban retrospektíve vizsgáltuk a CMV-infekció és -reaktiváció előfordulását 96 hematológiai beteg plazmamintáiból RT-PCR módszerrel, valamint értékeltük a betegek epidemiológiai jellemzőit. A betegek adatainak részletes feldolgozása az elektronikus adatbázis és kórlap-dokumentáció alapján történt. A CMV-szerológiai és PCR-vizsgálatokat a Központi Klinikai és Mikrobiológiai Diagnosztikai Intézet végezte a klinikus kérése alapján. A 24 hónapos periódusban 96 betegtől összesen 604 plazmaminta vizsgálatát végezték el. A betegeket megkülönböztettük az alapbetegség szerint (lymphoid 

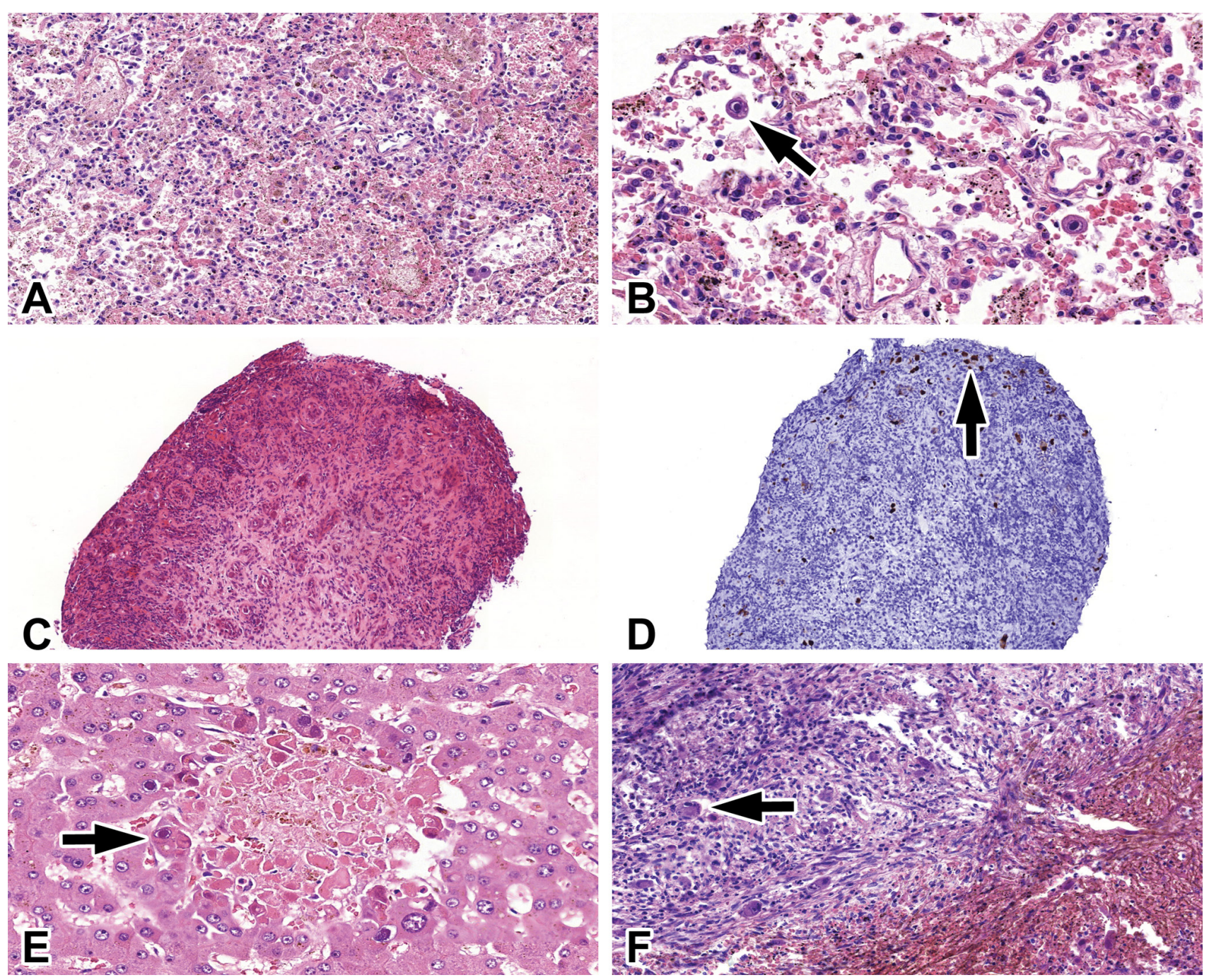

1. ábra
A) CMV-pneumonia; hematoxilin-eozin festés (20-szoros nagyítás)
B) CMV-pneumonia; hematoxilin-eozin festés (40-szeres nagyítás)
C) CMV-colitis biopsziás mintában; hematoxilin-eozin festés (10-szeres nagyítás)
D) CMV-colitis biopsziás mintában, CMV-ellenes immunhisztokémiai reakció (10-szeres nagyítás)
E) CMV-hepatitis; hematoxilin-eozin festés (40-szeres nagyítás)
F) CMV-oophoritis; hematoxilin-eozin festés (20-szoros nagyítás)

rendszer malignus betegségei, akut leukaemiák), továbbá aszerint, hogy végeztek-e autológ őssejt-transzplantációt vagy sem (ASCT/nem ASCT-s betegcsoport). A vizsgálatban részt vevők etikai engedélyt kértek a retrospektív, beavatkozással nem járó adatfeldolgozáshoz. Előzetes írásbeli beleegyező nyilatkozattal rendelkezett minden beteg a helyi szokásoknak megfelelően.

\section{CMV-kópiaszám-monitorozás és CMV-szerológiai státusz meghatározása}

A K2EDTA alvadásgátolt vérminta centrifugálása után a plazmamintából nukleinsav-izolálás történt MagNa Pure Compact Nucleic Acid isolation Kit I (Roche Switzerland) alkalmazásával a gyári előírásnak megfelelően. A víruskópiaszám meghatározására Artus CMV RT PCR
(Qiagen, Németország) kitet alkalmaztak. CMV-specifikus IgG- és IgM-antitest-meghatározás enzimimmunoassay- (EIA-) módszerrel történt ETI-CYTOK-M reverse Plus CMV IgM EIA (DiaSorin, Olaszország) és ETI-CYTOK-G Plus CMV IgG EIA (DiaSorin, Olaszország) kit alkalmazásával. Az IgM-assay diagnosztikus szenzitivitása és specificitása $100 \%$ és $99,71 \%, \mathrm{IgG}$-assay esetében pedig a szenzitivitás 99,59\%, a specificitás $100 \%$.

\section{$C M V$-reaktiváció- és betegségdefinició meghatározása}

CMV-reaktivációról beszélünk, ha a plazma- vagy egyéb mintából (légúti, liquorminta) nukleinsavat lehet detektálni. CMV-betegség „end organ disease” a klinikai tü- 
netek vagy radiológiai eltérés és szervi infekció együttes igazolása (a szövetminta hisztopatológiai vagy immunhisztokémiai jellegzetességei) alapján mondható ki (1. ábra) $[16,18]$.

\section{Kondicionáló kezelés}

Kondicionáló kezelésként az ASCT-csoportban a Hodgkin-lymphomás (HL) és non-Hodgkin-lymphomás (NHL) betegeknél BEAM (carmustine, etoposide, cytosine-arabinoside, melphalan) protokoll szerint történt, amelyet CD20-pozitív betegségekben anti-CD20 monoklonális ellenanyag $\left(375 \mathrm{mg} / \mathrm{m}^{2}\right)$ adásával egészítettünk ki [19]. Myeloma multiplexes (MM-) betegekben pedig melphalan $\left(200 \mathrm{mg} / \mathrm{m}^{2}\right)$ citosztatikus kezelést alkalmaztunk a -1 . napon $[20,21]$. Minden esetben nem manipulált autológ őssejtgraft került visszaadásra, átlagosan 4,94 $(2,74-7,1) \times 10^{6} /$ ttkg CD34-pozitív sejt.

\section{Szupportív terápia, antiinfektíp profilaxis}

Minden transzplantált beteget, illetve a nem ASCT-s csoportból azokat, akik purinanalóg-kezelésben részesültek, szűrt, leukodepletált és besugarazott vörösvérsejt- és thrombocytakészítménnyel szupportáltunk. ASCT-betegek antiinfektív profilaxisban részesültek a kondicionáló kezelés megkezdésétől. A neutropeniás időszakban napi $500 \mathrm{mg}$ levofloxacint és napi $100 \mathrm{mg}$ fluconazolt kaptak antibakteriális és antimikotikus profilaxisként. VZV-profilaxisként acyclovirt alkalmaztunk (1000 mg/nap per os adagban vagy táplálási nehezítettség, proffúz hasmenés esetén napi $2 \times 250$ mg iv. dózisban).

CMV-specifikus antivirális kezelést akkor kezdtünk, ha 2 egymást követő CMV-DNS-kópiaszám 1000 kópia/ ml feletti volt, vagy 1000 kópia/ml alatti értéket találtunk, de a 2 egymást követő minta kópiaszáma növekvő tendenciát mutatott.

\section{$C M V$-szerológiai státusz és CMV-DNS-monitorozás}

A CMV-DNS-monitorozást nem ASCT-s betegcsoportban olyan esetben végeztük, amikor a lázas epizód hátterében más ok nem igazolódott, kizárható volt a bakteriális fertőzés, invazív gombainfekció a tenyésztéses és egyéb laboratóriumi vizsgálatokkal (galaktomannanteszt), valamint képalkotó eljárásokkal (komputertomográfia - CT), valamint a láz nem az alapbetegség aktivitási tünete volt. Purinanalóg vagy monoklonális ellenanyag terápiában részesülő betegeknél lymphopenia során a CMV-infekció és a láz egyéb okainak elkülönítésére történt a vizsgálat. Autológ őssejttranszplantált betegeknél a kondicionáló kezeléstől a 30. poszttranszplantációs napig heti 1 alkalommal, ezt követően a 100. napig nem regulárisan történt vizsgálat elsősorban láz,
1. táblázat A betegek jellemzói (demográfiai adatok, hematológiai alapbe tegségek szerinti megoszlás az elvégzett autológ őssejt-transzplantáció arányában)

\begin{tabular}{lcc}
\hline Betegek száma & 96 & \\
Medián életkor, év (szórás) & $54(39-70)$ & \\
Nemek szerinti megoszlás & & \\
$\quad$ Férfi (\%) & $50(54)$ & \\
Nő (\%) & $46(46)$ & 23 \\
\hline Alapbetegség típusa & Betegek száma & ASCT-ben részesülő \\
& $(\%)$ & betegek száma \\
\hline Lymphoproliferativ betegségek & $83(86)$ & 30 \\
Non-Hodgkin-lymphoma & 26 & \\
Hodgkin-lymphoma & 11 & \\
Myeloma multiplex & 32 & \\
Akut leukaemia & $13(14)$ & \\
Akut myeloid leukaemia & 8 & \\
Akut lymphoid leukaemia & 5 & \\
\hline Összes beteg & $96(100)$ & \\
\hline
\end{tabular}

cytopenia miatt történő hospitalizáció kapcsán. Csak néhány esetben végeztünk PCR-vizsgálatot az őssejtgyûjtés idején. CMV-szerostátusz elemzése az ASCT-betegcsoportban az őssejt-mobilizációs eljárás előtt történt, míg a nem ASCT-s betegcsoportban a kemoterápiás kezelés megkezdése előtt nem végeztek minden esetben CMV-szerológiát.

\section{Eredmények}

A 24 hónapos vizsgálati periódusban 96 betegnél összesen 604 plazmaminta esetén történt CMV-DNS-PCRvizsgálat. A betegek demográfiai adatait az 1. táblázat mutatja. A medián életkor 54 év volt (tartomány 29-70 év), a betegek $54 \%$-a férfi $(\mathrm{n}=50)$. A vizsgált betegek 60\%-a 50 év feletti életkorú volt. A betegek többségét (83 [86\%]) lymphoproliferativ betegség miatt kezeltük, 14\%-ban akut leukaemia ( 5 betegnél akut lymphoid leukaemia [ALL], 8 betegnél akut myeloid leukaemia [AML]) volt a diagnózis. A 604 plazmamintából 46 esetben (7,6\%) igazolódott CMV-PCR-pozitivitás összesen 25 betegból (2. táblázat). A CMV-szerostátuszt 60 esetben vizsgáltuk, 43 beteg (72\%) rendelkezett CMVspecifikus IgG-ellenanyaggal, 17 (28\%) pedig szeronegatívnak bizonyult. A 96 beteg közül 63 esetben (65\%) végeztünk ASCT-t, a nem ASCT-s csoportban 33 beteget $(35 \%)$ kezeltünk különböző malignus hematológiai betegség miatt.

\section{Nem ASCT-s betegcsoport}

A vizsgált 96 betegból 33-at kezeltünk malignus hematológiai betegség miatt. Hat betegnél (18\%) lehetett CMV-PCR-pozitivitást észlelni (3 B-CLL, 1 MM, 2 T- 
2. táblázat $\mid$ Cytomegalovirus RT-PCR-pozitív minták megoszlása a betegszám függvényében

\begin{tabular}{llll}
\hline Paraméterek & CMV-PCR+ & CMV-PCR- & $\begin{array}{l}\text { Összes } \\
\text { mintaszám }\end{array}$ \\
\hline $\begin{array}{l}\text { Vizsgált plazmaminták } \\
\text { száma (\%) }\end{array}$ & $46(7,6)$ & $558(92,4)$ & $604(100)$ \\
Betegek száma (\%) & $25(26)$ & $71(74)$ & $96(100)$ \\
\hline
\end{tabular}

ALL). A reaktivációra utaló CMV-DNS-kimutatást megelőzően a betegek az alábbi kezelésben részesültek: a 3 B-sejtes krónikus lymphoid leukaemiás (B-CLL) beteg közül 2 alemtuzumab-, l pedig rituximab-bendamustin (R-B) kezelésben részesült, a 2 T-sejtes ALL-s beteg közül az egyik a német multicentrikus akut lymphoid leukaemia (GMALL) protokoll részeként nagy dózisú metotrexatot kapott, a másik relapsus kezelésére clofarabintartalmú kombinált kemoterápiát, a myeloma multiplexes beteg pedig bortezomibtartalmú kombinációt. A 6 pozitív CMV-PCR-eredménnyel bíró beteg közül 3 aszimptomatikus volt, 3 betegnél (1 T-ALL, 2 B-CLL) magas lázat lehetett észlelni, az egyik B-CLL-s idősebb nőbetegnél mellkasfelvételen interstitialis elváltozással, magas kópiaszámmal (640 000 kópia/ml). Pozitív tenyésztéses eredmény, bakteriális infekcióra, szepszisre vagy szisztémás gombafertőzésre utaló eltérés nem igazolódott egyiküknél sem. CMV-betegség, pneumonitis hisztológiai igazolása, BAL-mintavétel és annak PCRvizsgálata nem történt a beteg rossz általános állapota miatt.

3. táblázat |Autológ ôssejt-transzplantációban részesülő betegek és jellemzőik

\begin{tabular}{lc}
\hline Paraméterek & Betegek száma (\%) \\
\hline Non-Hodgkin-lyphoma & $23(36,5)$ \\
DLBCL & 9 \\
PTCL & 2 \\
MCL & 7 \\
FL & 5 \\
Hodgkin-lymhoma & $10(15,5)$ \\
Myeloma multiplex & $30(48)$ \\
Összes beteg & $63(100)$ \\
\hline Kondicionáló kezelés & \\
R-BEAM & 23 \\
BEAM & 10 \\
Melphalan 200 & 30 \\
Beadott CD34+ sejtek száma ttkg-onként, & $4,94 \times 10^{6}(2,74-7,1)$ \\
medián (szórás) &
\end{tabular}

BEAM = carmustine, etoposide, cytosine-arabinoside, melphalan; DLBCL = diffúz nagy B-sejtes lymphoma; FL = follicularis lymphoma; MCL = köpenysejtes lymphoma; PTCL = perifériás T-sejtes lympho$\mathrm{ma}$; $\mathrm{R}-\mathrm{BEAM}=$ rituximab-BEAM.

\section{ASCT-betegcsoport}

A 96 betegból 63 részesült nagy dózisú kemoterápiás kezelésben autológ perifériás őssejt-szupportációval. A betegek közül 30 (48\%) MM-es volt, 23 (36,5\%) NHL (9/ DLBCL, $7 / \mathrm{MCL}, 2 / \mathrm{PTCL}, 5 / \mathrm{FL})$ és 10 beteg $(15,5 \%)$ HL kemoszenzitív relapsusa miatt került transzplantációra (3. táblázat). Az ASCT-csoportban 19 betegben $(30,2 \%)$ a PCR-vizsgálat pozitív eredményt adott. A CMV-reaktiváció tünetmentes volt $13(68 \%)$ betegnél, majd spontán negatívvá vált, míg 6 esetben tünetekkel járt a reaktiváció. A leggyakoribb tünet volt a láz (6 esetben), majd hasmenés (2 beteg) és pancytopenia, elhúzódó engraftment ( $1-1$ beteg). Egy betegnél alakult ki akut respiratorikus distressz szindróma (ARDS), légzési elégtelenség, amelynek hátterében post mortem szövettanilag lehetett igazolni a CMV-pneumoniát (1. A) és B) ábra). A CMV-PCR-pozitív eredmények jelentôs hányadát $(42 \%)$ a transzplantációt követő $20-40$. nap között lehetett detektálni, 5 betegnél a 10-20. nap között, 3 betegben pedig a 100. nap után. A PCR-pozitív minták kópiaszáma 1000 kópia/ml alatt volt 32 (69\%) esetben.

\section{Anti-CMV-kezelés és terápiás válasz}

Összesen 9 beteg részesült CMV-ellenes kezelésben ( 3 beteg nem ASCT-s, 6 pedig az ASCT-csoportból). Nyolc esetben intravénás gancyclovirt alkalmaztunk 5 $\mathrm{mg} / \mathrm{ttkg}$ dózisban napi 2 részletben, 1 betegnél pedig valgancyclovirt napi $900 \mathrm{mg}$ összdózisban. Egy transzplantált beteg a megkezdett antivirális kezelés ellenére progresszív légzési elégtelenség, ARDS következtében elhunyt. A CMV-ellenes terápiát a klinikai tünetek oldódásáig és 2 egymást követő negatív vagy csökkenő CMVPCR-eredmény eléréséig folytattuk. A kezelés befejeztével ismételt CMV-reaktivációt nem észleltünk.

\section{Megbeszélés}

A malignus hematológiai betegségek kezelése során egyre növekvő számban alkalmazott súlyos és tartós sejt mediálta immunkárosodást előidéző szerek következményeként a Herpesviridae család tagjai által okozott reaktiváció és fertőzés (ezen belül is a CMV-infekció mint opportunista fertőző ágens) jelentősége növekedett [22]. Különösen aktuálissá tette ennek vizsgálatát az immunterápiás szerek, valamint immunmoduláló és proteaszómagátlók bevezetése a lymphomák és myeloma multiplex kezelésében. Limitált az irodalmi adatok száma, hogy MM- és NHL-betegek autológ össejt-transzplantációját követóen, illetve hematológiai betegek nagy dózisú kemoterápiás kezelése után milyen arányban fordul elő CMV-infekció [8, 13, 16, 23-25]. A nemzetközi irodalmi tanulmányok alapján a CMV-reaktiváció incidenciája 30-40\% körüli akkor, ha regulárisan monitorozzák a betegeket PCR-alapú metodikával vagy antigenaemia-módszerrel, míg 1-13\% közötti, ha a klinikai tünetek 
alapján valószínúsítik a CMV-infekciót. Magasabb arányban fordul elő reaktiváció lymphoproliferativ betegségben, valamint abban a betegcsoportban, amelynek tagjainál jelentős a T-sejt-funkció-károsodás (alemtuzumab-, fludarabin-, clofarabin-, cladribintartalmú kezelést követően) $[1,7,13]$. ASCT-t követően a CMV-infekció előfordulása alacsony [2]. Holmberg és mtsai azonban a transzplantációt követő 100 napban CD34+-szelektált graft esetén magasabb arányban észleltek reaktivációt $(22,6 \%)$, mint nem manipulált graft esetén (4,2\%) [26]. Autológ őssejt-transzplantáltakban preemptív antiCMV-terápia alkalmazása esetén nem alakult ki CMVbetegség [27]. Crippa és mtsai ASCT kapcsán 2\%-ban figyeltek meg CMV-pneumoniát, amely a transzplantációt megelőző CMV-szeropozitivitással függött össze [28]. Vizsgálatainkban a 2012-2014 közötti időszakban vizsgált 604 plazmamintából 46 (7,6\%) lett CMV-PCRpozitív, összesen 25 betegből (19 ASCT, 6 nem ASCT-s csoportból). Nagyobb arányú volt a reaktiváció az ASCT-csoportban (30,2\%), összehasonlítva a nem transzplantált betegekkel (18\%). Minden esetben a lymphoid rendszer malignus betegségeiben jelentkezett a reaktiváció, AML-ben egyetlen betegnél sem észleltünk CMV-PCR-pozitivitást. Han és mtsai (2007) hasonló eredményre jutottak, amikor CMV pp65 antigenaemia assay alkalmazásával vizsgálták a reaktiváció előfordulását. Szignifikánsan magasabb volt az arány lymphoproliferativ betegségekben, mint a myeloid rendszer malignus betegségei esetén (13,6\% vs. 3,9\%,p = 0,001) [13]. Megfigyeléseink alapján a nem ASCT-s betegcsoportban 3 esetben tünetekkel járó reaktivációt lehetett dokumentálni, minden esetben magas lázat észleltünk, amely más okkal nem volt összefüggésben (negatív bakteriális tenyésztési eredmény és normális prokalcitoninérték mellett). CMV-betegség (pneumonitis) igazolására további vizsgálat, bronchoalveolaris mosás (BAL-CMV-PCR, szövettani minta ez irányú vizsgálata) nem történt. Ausztráliai centrum (Peter MacCallum Cancer Center) munkacsoportja vizsgálta a CMV infekció/reaktiváció előfordulását hematológiai betegekben különböző kemoterápiás kezelések kapcsán (hyper-CVAD [cyclophosphamid, vincristin, doxorubicin, dexamethason, metotrexat és cytarabin], fludarabintartalmú, rituximab-, alemtuzumabkezelés) és ASCT esetén. A CMV-reaktiváció $4,6 / 4,2 / 9,7 / 2,6$ és $50 \%$ volt azoknál a betegeknél, akiket fludarabin/ASCT/hyper-CVAD/rituximab/alemtuzumab terápiában részesítettek [8]. Hasonlóan a nem ASCT-s betegcsoportunkban a 6 reaktiváció közül 2 beteg purinanalóg-, 2 alemtuzumabkezelésben részesült (3 esetben a reaktiváció tünetekkel járt). Az ASCTbetegcsoportban a CMV-PCR-pozitív betegek közül 1 a transzplantációt megelőzően hyper-CVAD-kezelésben részesült. Eredményeink hasonlóak a korábban publikált megfigyelésekhez $[5,8,13,26]$. Marchesi és mtsai 327, ASCT-ben részesített betegből 36 esetben (11\%-ban) észlelték CMV-reaktiváció és -betegség előfordulását, és alkalmaztak anti-CMV-terápiát ASCT-t követően. A re- aktivációt nagyobb arányban észlelték NHL-es betegek esetén (16\%), míg MM-es betegeknél csak 8\%-ban fordult elő [25]. Adataink alapján az ASCT-betegcsoportban nagyobb arányú volt a reaktiváció (30,2\%), amely a nagyon érzékeny kvantitatív PCR-metodika következménye lehet. Ugyanakkor Marchesi és mtsai által vizsgált betegcsoporttal összehasonlítva, az általunk vizsgált és autológ őssejt-transzplantációban részesített betegek száma jelentősen kisebb [25]. A 19, transzplantációt követő reaktiváció hasonló arányban fordult elő lymphoma és MM miatt kezelt betegekben $(10 \mathrm{HL}+\mathrm{NHL}$ eset [30\%], 9 MM-eset [30\%] betegnél). Aszimptomatikus reaktiváció 13 esetben fordult elő, míg 6 esetben lehetett klinikai tünetekkel összefüggésben észlelni. A vezető klinikai tünet minden esetben a más okkal nem magyarázható láz volt, 1-1 esetben pedig elhúzódó megtapadást, a neutropenia, mucositis rendeződése után újra megjelenő hasmenést lehetett észlelni. (A széklettenyésztés, Clostridium difficile toxin vizsgálata minden esetben negatív volt ezekben a betegekben.) Egy betegben alakult ki CMV-betegség 6225 kópia/ml értékkel. Radiológiailag interstitialis pneumonia, ARDS igazolódott, a beteg állapota a megkezdett antivirális kezelés ellenére gyorsan romlott, és légzési elégtelenség tünetei közt exitált 2 nappal később. A post mortem hisztológiai vizsgálat bizonyította a feltételezett CMV-pneumonitist. Korábbi irodalmi közlések alapján CMV-pneumonia előfordulási aránya alacsony (2-9\%) ASCT-n átesett betegekben, azonban súlyos progresszív lefolyású, és időben megkezdett adekvát kezelés ellenére is magas a mortalitása [8, 29, 30]. Összhangban az ECIL-4-ajánlással, CMVPCR-rel történő rutinmonitorozás nem javasolt ASCT-n átesett betegeknek vagy olyan esetekben, ha nem fludarabintartalmú vagy alemtuzumabkezelésben részesül a beteg. Vizsgálatunk alapján a CMV-reaktiváció és -betegség előfordulási aránya alacsony (26\% és 2\%). Azonban CMV-infekcióra vagy betegségre utaló klinikai tünetek megjelenése esetén a PCR-technika alkalmazása lehetővé teszi a korai preemptív anti-CMV-terápia megkezdését és ezáltal a kemoterápiával, transzplantációval összefüggő mortalitás incidenciájának csökkenését eredményezheti.

Anyagi támogatás: A közlemény megírása anyagi támogatásban nem részesült.

Szerzôi munkamegosztás: P. K.: A beteganyag gyưjtése, a kézirat megfogalmazása, szerkesztése, a képi anyagok összegyưjtése, a hipotézisek és a konklúzió kidolgozása. T. G.: A betegek plazmamintáinak feldolgozása, értékelése, a kézirat szerkesztése, a konklúzió kidolgozása. B. Á., G. P. T.: A betegek vizsgálata, kezelése. B. Z.: A betegek vizsgálata, kezelése, követése, a betegek vizsgálati eredményeinek, adatainak elérhetôvé tevése, lektorálás. K. B.: Képi anyag összegyưjtése. U. E.: Lektorálás. 
Témavezető. A kézirat végleges változatát valamennyi szerző elolvasta és jóváhagyta.

Érdekeltségek: A szerzőknek nincsenek érdekeltségeik.

\section{Irodalom}

[1] Angarone, M.: Epidemiology and prevention of viral infections in patients with hematologic malignancies. Infect. Disord. Drug Targets, 2011, 11(1), 27-33.

[2] Wade, J. C.: Viral infections in patients with hematological malignancies. Hematology Am. Soc. Hematol. Educ. Program, 2006, 368-374.

[3] Busca, A.: Viral infections in patients with hematological malignancies. Leukemia Suppl., 2012, 1(2), S24-S25.

[4] Duvall, C. P., Casazza, A. R., Grimley, P. M, et al.: Recovery of cytomegalovirus from adults with neoplastic disease. Ann. Intern. Med., 1966, 64(3), 531-541.

[5] Bilgrami, S., Aslanzadeh, J., Feingold, J. M., et al.: Cytomegalovirus viremia, viruria, and disease after autologous peripheral blood stem cell transplantation: no need for surveillance. Bone Marrow Transplant., 1999, 24(1), 69-73.

[6] Nguyen, Q., Estey, E., Raad, I., et al.: Cytomegalovirus pneumonia in adults with leukemia: an emerging problem. Clin. Infect. Dis., 2001, 32(4), 539-545.

[7] Keating, M. J., Flinn, I., Jain, V., et al.: Therapeutic role of alemtuzumab (Campath- $1 \mathrm{H})$ in patients who have failed fludarabine: results of a large international study. Blood, 2002, 99(10), 3554-3561.

[8] Ng, A. P., Worth, L., Chen, L., et al.: Cytomegalovirus DNAemia and disease: incidence, natural history and management in settings other than allogeneic stem cell transplantation. Haematologica, 2005, 90(12), 1672-1679.

[9] Morrison, V. A., Rai, K. R., Peterson, B. L.: Impact of therapy with chlorambucil, fludarabine, or fludarabine plus chlorambucil on infections in patients with chronic lymphocytic leukemia: Intergroup Study Cancer and Leukemia Group B 9011. J. Clin. Oncol., 2001, 19(16), 3611-3621.

[10] Morrison, V. A.: Infectious complications of chronic lymphocytic leukaemia: pathogenesis, spectrum of infection, preventive approaches. Best Pract. Res. Clin. Hematol., 2010, 23(1), 145153.

[11] Hermouet, S., Sutton, C. A., Rose, T. M., et al.: Qualitative and quantitative analysis of human herpesviruses in chronic and acute B cell lymphocytic leukemia and in multiple myeloma. Leukemia, 2003, 17(1), 185-195

[12] Chemaly, R. F., Torres, H. A., Hachem, R. Y., et al.: Cytomegalovirus pneumonia in patients with lymphoma. Cancer, 2005, 104(6), 1213-1220.

[13] Han, X. Y.: Epidemiologic analysis of reactivated cytomegalovirus antigenemia in patients with cancer. J. Clin. Microbiol., 2007, 45(4), 1126-1132.

[14] Asano-Mori, Y., Oshima, K., Sakata-Yanagimoto, M., et al.: High-grade cytomegalovirus antigenemia after hematopoietic stem cell transplantation. Bone Marrow Transplant., 2005, 36(9), 813-819.

[15] Boeckh, M., Ljungman, P.: How we treat cytomegalovirus in hematopoietic cell transplant recipients. Blood, 2009, 113(23), $5711-5719$

[16] Ljungman, P., de la Camara, R., Cordonnier, C., et al.: Management of CMV, HHV-6, HHV-7 and Kaposi-sarcoma herpesvirus
(HHV-8) infections in patients with hematological malignancies and after SCT. Bone Marrow Transplant., 2008, 42(4), 227240.

[17] Zhang, S., Zhou, Y. H., Li, L., et al.: Monitoring human cytomegalovirus infection with nested PCR: comparison of positive rates in plasma and leukocytes and with quantitative PCR Virol. J., $2010,7,73$.

[18] Ljungman, P., Griffiths, P., Paya, C.: Definitions of cytomegalovirus infection and disease in transplant recipients. Clin. Infect. Dis., 2002, 34(8), 1094-1097.

[19] Chopra, R., Linch, D. C., McMillan, A. K., et al.: Mini-BEAM followed by BEAM and ABMT for very poor risk Hodgkin's disease. Br. J. Haematol., 1992, 81(2), 197-202.

[20] Barlogie, B., Hall, R., Zander, A., et al.: High-dose melphalan with autologous bone marrow transplantation for multiple myeloma. Blood, 1986, 67(5), 1298-1301.

[21] Attal, M., Harousseau, J. L., Stoppa, A. M., et al.: A prospective, randomized trial of autologous bone marrow transplantation and chemotherapy in multiple myeloma. N. Engl. J. Med., 1996, $335(2), 91-97$

[22] Nucci, M., Anaissie, E.: Infections in patients with multiple myeloma in the era of high-dose therapy and novel agents. Clin. Infect. Dis., 2009, 49(8), 1211-1225.

[23] Rossini, F., Terruzzi, E., Cammarota, S., et al.: Cytomegalovirus infection after autologous stem cell transplantation: incidence and outcome in a group of patients undergoing a surveillance program. Transpl. Infect. Dis., 2005, 7(3-4), 122-125.

[24] Marchesi, F., Mengarelli, A., Giannotti, F., et al.: High incidence of post-transplant cytomegalovirus reactivations in myeloma patients undergoing autologous stem cell transplantation after treatment with bortezomib-based regimens: a survey from the Rome transplant network. Transpl. Infect. Dis., 2014, 16(1), 158-164.

[25] Marchesi, F., Pimpinelli, F., Gumenyuk, S., et al.: Cytomegalovirus reactivation after autologous stem cell transplantation in myeloma and lymphoma patients: a single-center study. World J. Transplant., 2015, 5(3), 129-136.

[26] Holmberg, L. A., Boeckh, M., Hooper, H., et al.: Increased incidence of cytomegalovirus disease after autologous CD34-selected peripheral blood stem cell transplantation. Blood, 1999, 94(12), 4029-4035.

[27] Ruell, J., Barnes, C., Mutton, K., et al.: Active CMV disease does not always correlate with viral load detection. Bone Marrow Transplant., 2007, 40(1), 55-61.

[28] Crippa, F., Holmberg, L., Carter, R. A., et al.: Infectious complications after autologous CD34-selected peripheral blood stem cell transplantation. Biol. Blood Marrow Transplant., 2002, $8(5), 281-289$.

[29] Ljungman, P., Biron, P., Bosi, A., et al.: Cytomegalovirus interstitial pneumonia in autologous bone marrow transplant recipients. Infectious Disease Working Party of the European Group for Bone Marrow Transplantation. Bone Marrow Transplant., 1994, 13(2), 209-212.

[30] Konoplev, S., Champlin, R. E., Giralt, S., et al.: Cytomegalovirus pneumonia in adult autologous blood and marrow transplant recipients. Bone Marrow Transplant., 2001, 27(8), 877-881.

(Piukovics Klára dr., Szeged, Semmelweis u. 8., 6721 e-mail: piukovics.klara@gmail.com) 